\title{
Oceanography
}

CITATION

Ryan, W.B.F. 2012. Review of Soundings: The Story of the Remarkable Woman Who Mapped the Ocean Floor, by H. Felt. Oceanography 25(4):75-77, http://dx.doi.org/10.5670/oceanog.2012.110.

DOI

http://dx.doi.org/10.5670/oceanog.2012.110

COPYRIGHT

This article has been published in Oceanography, Volume 25, Number 4, a quarterly journal of The Oceanography Society. Copyright 2012 by The Oceanography Society. All rights reserved.

USAGE

Permission is granted to copy this article for use in teaching and research. Republication, systematic reproduction, or collective redistribution of any portion of this article by photocopy machine, reposting, or other means is permitted only with the approval of The Oceanography Society. Send all correspondence to: info@tos.org or The Oceanography Society, PO Box 1931, Rockville, MD 20849-1931, USA. 


\section{Soundings: The Story of the Remarkable Woman Who Mapped the Ocean Floor}

By Hali Felt, Henry Holt \& Company,

2012, 352 pages, ISBN 978-0-80-5092158,

Hardcover, \$30 US

\section{REVIEWED BY WILLIAM B.F. RYAN}

Indeed, the life of a remarkable woman comes alive in Soundings by Hali Felt, published this past summer by Henry Holt \& Company. I had the opportunity to befriend, work with, admire, cajole, mourn with, and visit with Marie Tharp from 1962 until her death in 2006. Her co-conspirator in mapping the ocean floor was Bruce Heezen, the mentor of my $\mathrm{PhD}$ dissertation at the LamontDoherty Geological Observatory of Columbia University. In fact, when I arrived at Lamont, my office was so close to the module in which she sketched those extraordinary physiographic diagrams that I could hear her pen scratch across the drafting sheet as well as the common "oh dear" she would utter just seconds before the interminable rubbings of her eraser. Hundreds and hundreds of rubbings, followed by curses from Bruce, and the arguments back and forth would become an indelible part of my own education about how our planet works.

I was introduced to "The Floors of the Oceans 1. The North Atlantic" (Heezen, Tharp, and Ewing, 1959, Geological Society of America Special Paper 65) right out of college and aboard the Research Vessel Chain of the Woods Hole Oceanographic Institution, on a voyage from Boston to Istanbul and back. It was a thin, but dense book bound in green fabric with a foldout chart that would forever become my mental image of the hidden abyss. The reader of Soundings will learn of the rift valley that runs along the axis of the mid-ocean ridge and how this valley would make Marie and Bruce famous, but most scientists have forgotten that in that first portrayal, the ridge flanks were stepped by successive escarpments. Yet, our own echosoundings aboard the Chain did not reveal these steps. When I met Marie the following year, I remarked upon this incongruence. But she was already leaps ahead. She had realized that the scarps only appeared on ship tracks oblique to the strike of the ridge axis. They turned out to be fracture zones, ocean-crossing clefts that she had successfully deciphered in the equatorial Atlantic and had then introduced in her recent diagram of the South Atlantic. If you didn't believe in continental drift before, you were converted by Marie's images of these flow lines that appeared to be almost like railroad tracks linking Africa with South America.

Marie had now turned her attention to mapping the floor of the Indian Ocean, a daunting task considering the sparseness of prior expeditions. It was only then that I learned that she had been provided with soundings from Soviet expeditions. While struggling with defining the midocean ridge as it circled between South Africa and Antarctica, she had started to draw the fracture zones on trends from west to east, following the orientations of those in the South Atlantic. Then, one day, came an explosion. Marie had torn

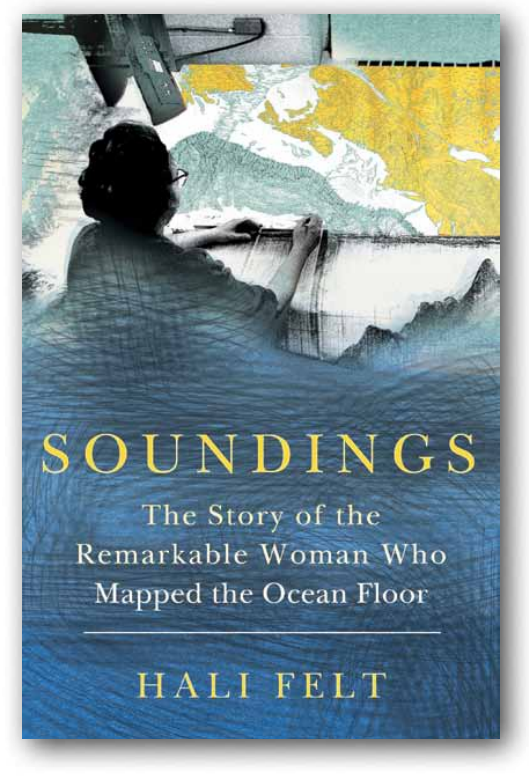

up her whole sheet, cut it to sheds with scissors. Bruce was furious, erupting like an Icelandic volcano: "How could you do it?" followed by further expletives.

"It just doesn't work!" she replied. The students all rushed in to witness the commotion that turned out to be an extraordinary learning experience. Marie told Bruce outright to forget his expanding Earth hypothesis. It was dead as far as she was concerned. She explained that they must first reassemble all of the continents. Madagascar should not slide west onto South Africa, but rather arrive from the north when rifted off Somalia. India tucked in neatly against Madagascar. Marie then began to sketch the configuration on the white plaster globe that always stood next to her illuminated drafting table. She told us that she had been trained in mathematics, and that it was necessary to use a spherical representation to bring the continental edges together. Suddenly, the fracture zone orientations on the Southwest Indian Ridge flipped 90 degrees. Later, I asked her what ignited this idea. She said that the revelation began when she was mapping the 
orientation of the Owen Fracture Zone at the mouth of the Gulf of Aden following its exploration in 1958 by the Lamont Research Vessel Vema. "Everything must fit together," she posited. "If I can deduce the relative motion of India with respect to Madagascar, and Madagascar to Africa, and Africa to Antarctica, and Antarctica to Australia, I can figure out all of the fracture zone trends and then use earthquakes to define the mid-ocean ridge axis." This was my first lesson in what soon would become the new global tectonics and evolve into the concept that Earth's plates are simply rigid caps rotating around Euler poles on a sphere.

Hali Felt's Soundings dwells on an ugly period she calls "The Harassment." Conflict between Bruce and Doc Ewing, director of Lamont, began with some quite bad behavior on Bruce's part following his departure as chief scientist on a Vema expedition in the South Pacific. It then commenced in earnest following the Second International Oceanographic Congress held in Moscow in June 1966.

I was at the Congress, having been awarded a travel fellowship from the National Academy of Sciences. Great excitement had erupted two months earlier at the spring meeting of the American Geophysical Union (AGU) concerning the patterns of symmetric magnetic anomalies over the mid-ocean ridges that now strongly confirmed the Fred Vine and Drumm Matthews hypothesis of seafloor spreading. Yet, at the Moscow Congress, in session after session, Soviet scientists were professing that the ocean floor was foundered continental crust.

When the subject of the magnetic stripes was raised, all Soviet presentations placed the sources for these signals deep in the mantle, a physical impossibility due to the high temperatures at those depths well above the Curie point for ferromagnetic materials. During my own talk on the convergence of Africa and Europe in the Mediterranean Sea and the formation of an accretionary prism that would someday become a mountain range, there was actual shoe pounding, just like Nikita Khrushchev's shoe-banging incident in the UN General Assembly in 1960. Of course, this blatant objection by Soviet presenters to continental drift and seafloor spreading aroused the interest of the press. Thus, it was in this context that Heezen's discussion of his student's discovery of magnetic reversals recorded in deep-sea cores, as presented at the previous AGU meeting, received so much attention. With prompting from UNESCO, the apparent conflict between Soviet and American oceanographers resulted in a hastily arranged press conference. A brief article in The New York Times about the Congress failed to mention the names of the presenters at AGU, and mistakenly credited Heezen with

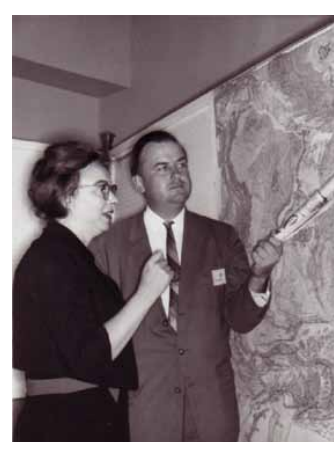

$$
\begin{array}{r}
\text { (Above) Marie Tharp } \\
\text { and Bruce Heezen } \\
\text { in undated photo. } \\
\text { (Right) Marie Tharp in } \\
\text { her office at Columbia } \\
\text { University's Lamont } \\
\text { Geological Observatory, } \\
\text { circa 1959. Photos cour- } \\
\text { tesy of Lamont-Doherty } \\
\text { Earth Observatory }
\end{array}
$$

discovery of the magnetic reversals. The publicity inflamed the tempest that had already begun at Lamont.

In my opinion, Hali Felt fails to give ample attention in Soundings to outreach by subsequent Lamont directors to Marie and the restoration of mutual warmth and affection. This reconciliation led, upon Marie's death, to a major bequest to Columbia University that now sponsors the Marie Tharp Fellowships in the Earth, Environmental, and Ocean Sciences. I also feel that Soundings does not recognize Bruce Heezen's vital intellectual contribution to the mapping efforts. I was with Bruce and Marie aboard the Research Vessel Kane in 1968 when our goal was to chart a single fracture zone across the entire North Atlantic in order to establish the pattern for that year's physiographic diagram. Bruce was very much the guiding force and knew that subbottom profiling with airgun sound sources was necessary to image the cleft where it was deeply buried by sediment beneath the continental rises and abyssal plains and thus hidden from echosoundings. Bruce also took full advantage of his large entourage of graduate students to cast a wide net across 
the field of marine geology and geophysics. He attended every major society meeting, which always included his contributions to a dozen or more abstracts, whereas Marie mostly remained isolated in her module at Lamont or in her home in South Nyack, New York. Upon Bruce's sudden death in 1977 and the soon-after publication of the World Ocean Floor panorama painted by Heinrich Berann, Marie's ambitions for continued ocean floor mapping essentially ceased.
At a 2001 ceremony honoring Marie Tharp's accomplishments, I superimposed the 1977 panorama over the current digital compilation of predicted bathymetry using satellite-derived gravity to reveal the astonishing similarity of all of the fracture zone trends. The very fine-scale segmentation of the mid-ocean ridge spreading centers first detailed in the 1968 diagram - to great criticism at the time-was confirmed. That the Tharp-Heezen partnership could achieve this level of accuracy with such sparse coverage of actual soundings must mean that the mapping of the ocean floor was accomplished not by the soundings alone, but by a prescient understanding of how the earth works. 四

William B.F. Ryan (billr@ldeo.columbia. edu) is Special Research Scientist, LamontDoherty Earth Observatory and Adjunct Professor Emeritus, Columbia University, Palisades, NY, USA.

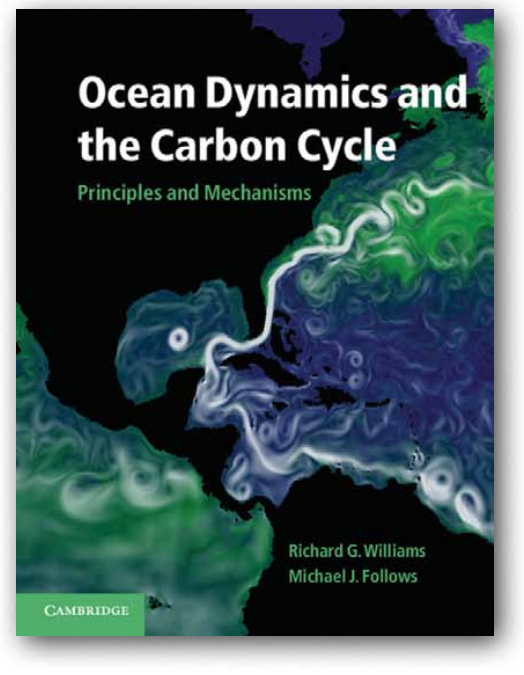

expertise to write a book targeted at honors undergraduate or graduate students, as well as at professionals in ocean science who need to learn the fundamentals of disciplines outside their own. The authors began their science careers in physical oceanography and atmospheric sciences, respectively, at the University of East Anglia. Each evolved toward a strong research interest in ocean biogeochemistry, though from their own unique perspectives of ocean circulation and biogeochemical modeling. The content and structure of the book reflects this training and these interests.

The book's two introductory chapters constitute Part I, describing the ocean in broad terms and in global relevance.
Ocean heat storage and transfer, the global ocean carbon budget, and climate are treated in the first chapter, followed by quick surveys of descriptive physical oceanography and the essentials of life, nutrients, and carbon in the ocean. The four chapters of Part II cover the fundamentals of ocean transport (with a strong focus on tracers of many transport/mixing processes), the physics of circulation, biological processes, and the inorganic carbon system. The authors describe Part III as "physical phenomena and their biogeochemical signals." It begins with a chapter on seasonality, which includes physical, biological, and biogeochemical temporal variability. Then, three chapters focusing on ocean physical phenomena (gyres and intense currents, eddies, and ventilation) are followed by one that seeks to tie ocean physics to upper-ocean biological systems and the nutrient fields in the ocean interior. The section closes with a chapter on the deepest realms of the ocean and overturning circulation. Finally, Part IV synthesizes at the level of the Earth system, considering variations in the ocean-atmosphere carbon cycle, the fate of fossil fuel $\mathrm{CO}_{2}$, and glacial-interglacial changes in atmospheric $\mathrm{CO}_{2}$.

Each chapter offers approximately four end-of-chapter questions, commonly written such that they add more insights on the system considered. These questions force the reader to delve more deeply into the concepts; presumably the authors will provide the solutions if requested! Also, at the conclusion of each chapter is a recommended reading list that includes useful descriptions of why the authors recommend the readings. 